\title{
PRELIMINARY REPORT ON THE CORE DRILLINGS IN THE RADIOACTIVE ROCKS OF KVANEFJELD IN THE ILÍMAUSSAQ INTRUSION
}

\section{Bjarne Leth Nielsen}

During the summer of 1969 seven core drillings were made on Kvanefjeld in the Ilimaussaq intrusion in an attempt to determine the geological relations of the U- and Th-bearing rocks (Sørensen, 1969). Prior to this investigation, 36 holes had been drilled in 1958 and 1962. A detailed geological map has been published (Sørensen, Hansen \& Bondesen, 1969) and a series of surface radiometric investigations have been made in the area concerned.

In general Kvanefjeld comprises an extensive intrusion breccia, in which lujavrite, the youngest rock, forms the matrix. The older intrusive rocks and supracrustals are found as blocks of very variable size and proportion within the breccia. Tectonic disturbances, dyke intrusion and late hydrothermal activity have influenced the geological patterns in a complicated way.

The concentration of radioactive minerals is most intense in places where lujavrite has come in contact with the lavas which form the roof of the intrusion. Furthermore, $\mathrm{U}$ mineralisation has taken place in NE-SW striking deformation zones. The radioactive rocks are found in scattered localities (Sørensen, Hansen \& Nielsen, 1969). The largest area is situated in the central part of Kvanefjeld near a trial excavation, called the mine area. In addition to this area, two additional areas of economic interest are found. One is on the north-eastern edge of the plateau, and one in the north, near the pegmatite which forms the northern boundary between the intrusion and the surrounding lavas. Between the central area and the two smaller ones a narrow radioactive zone in deformed gabbro has been the subject of investigation. The zone is impregnated with lujavrite.

The 1969 drilling programme had the following aims:

1. To establish the depth of the radioactive occurrences in the mine area. The depth of the earlier drillings was not sufficient to answer this question.

2. To drill through the north-eastern and northern radioactive areas, which had not been drilled previously. The drillings should primarily give information about the extension of the $\mathrm{U}$ mineralisation below the surface.

3. To examine the depth and the volume of the $U$ mineralisation in the deformed gabbro zone. 
4. In combination with the earlier drillings to provide a basis for calculations of the radioactive ore tonnage.

The depth of the seven holes varied from $36 \mathrm{~m}$ to $450 \mathrm{~m}$. The purposes of the drilling programme, as outlined above, were to some extent realised. A summary of the main results is given below.

1. Two drillings, one in the south-eastern and one in the north-western part of the mine area, show that radioactive rocks of significant activity probably cannot be expected more than $175 \mathrm{~m}$ below the surface. A possible continuation below the cover of other rocks further towards the north-west may be present. Previously the $\mathrm{U}$ tonnage in this area was calculated to be 4000 tons, and with present knowledge this estimate may be increased to some degree. Within the radioactive layer the $U$ concentration varies strongly. This is due, at least in the north-west, to the presence of a large number of inclusions of earlier rocks.

2. Towards the north-east the surface radioactivity is rather high, and this active layer continued in the drill core to a depth of $28 \mathrm{~m}$. A highly radioactive zone of lujavrite, which at a lower altitude can be followed along the eastern slope of Kvanefjeld, was not encountered in the drilling. This zone is probably a rather irregular and thin one whose distribution is due to the zones of deformation in the older gabbro dykes and lavas.

In contrast, the northern area consists to a great depth of vary homogeneous lujavrite of medium to high radioactivity. A drilling with a southerly inclination showed that the activity decreases steadily downwards, but is still relatively high at a depth of $150 \mathrm{~m}$. A drilling with a northerly inclination indicated that highly radioactive rocks cannot be expected towards the north below the lava cover.

3. The steep and thin radioactive, lujavrite-impregnated, deformed gabbro zone was intersected in one drill hole which however gave no information about its depth in the central part of the zone. This zone does not seem to be of economic interest. Further south-west towards the mine area, where the zone is broader, it forms a culmination around a central core of deformed gabbro. The northern radioactive limb of this culmination could be followed in the drilling to a depth of about 100 metres. There is probably a connection between this point and the radioactive rocks in the north-western part of the mine area.

4. The former calculations of the entire $U$ tonnage were made exclusively with reference to the rocks of the mine area (1), an area with the shape of a polygon determined by the outermost drill holes. Following this summer's drillings, the area which formed the basis for these calculations can be extended somewhat towards the north-west, and in addition the western part of the narrow deformation zone (3) may be incorporated. Furthermore attention must be drawn to the northern part of $\mathrm{Kvanefjeld}$ (2), where homogeneous medium active lujavrite is present in considerable amounts.

$\gamma$-logging has been undertaken in all drill holes, and continuous $\mathrm{U}$ and Th de- 
terminations will be carried out at the Atomic Energy Commission's laboratories at Risø. An integration of the log-curves will also be prepared. These results, together with the geological observations, will form the basis for new calculations of the $\mathrm{U}$ tonnage on Kvanefjeld.

\section{References}

Sørensen. H. 1969 : Field work in the Ilimaussaq intrusion. Rapp. Gronlands geol. Unders. 19, $37-38$.

Sørensen, H., Hansen, J. \& Bondesen, E. 1969: Preliminary account of the geology of the Kvanefjeld area of the Ilímaussaq intrusion, South Greenland. Rapp. Gronlands geol. Unders. 18.

Sørensen, H., Hansen, J. \& Nielsen, B. Leth 1969: Rapport over undersøgelser af uranforekomsterne på Kvanefjeldsplateauet 1964-1968 med et forslag til et nyt boreprogram. Internal GGU report.

\section{, \\ THE INTERNATIONAL HYDROLOGICAL DECADE PROGRAMME IN NARSSAQ RIVER VALLEY, SOUTH GREENLAND}

\section{Leo Larsen}

The Hydrological Decade Programme in Narssaq river valley started in 1965. In 1966 and 1967 work was concentrated on establishment of decade stations in order to collect data concerning precipitation, runoff, evapotranspiration and reservoirs. Collection of these basic data is of major importance for the calculation of the water balance and at the end of the summer 1969 these parameters were being investigated as follows:

Mean precipitation is to be calculated from 6 precipitation gauges placed in the $33 \mathrm{~km}^{2}$ area according to the topography.

It is most important in runoff studies to establish the stage-discharge relations. Determination of stage is being made by five water stage recorders of which three are placed at points along the Narssaq river and two in the tributaries. The main hydrometric station measuring the total runoff is placed in the Narssaq river close to the sea.

Field measurement of evapotraspiration is very difficult and instead of this, a theoretical approach based on the physics of the evapotranspiration process is used. To collect the data needed, four weather stations have been placed in the area measuring maximum, minimum and actual temperature, relative air humidity, atmospheric pressure, velocity and direction of the wind.

The reservoirs are Narssaq glacier, Taseq lake and groundwater.

Detailed studies of Narssaq glacier were started in 1967 and have not been finished 